\title{
Clinical and laboratory evaluation of premature goat kids with and without antenatal corticotherapy
}

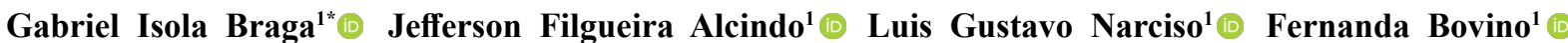 Thomas Alexander Trein ${ }^{1}$ Juliane Teramachi Trevizan ${ }^{1}\left[\right.$ Murilo Catelani Ferraz $^{2}$ Francisco Leydson Formiga Feitosa ${ }^{3}[$}

${ }^{1}$ Programa de Pós-graduação em Ciência Animal, Departamento de Clínica, Cirurgia e Reprodução Animal, Faculdade de Medicina Veterinária de Araçatuba (FMVA), Universidade Estadual Paulista (UNESP), 01049-010, Araçatuba, São Paulo, Brasil. E-mail: gabrielisolabraga@gmail.com. "Corresponding author.

${ }^{2}$ Curso de Medicina Veterinária, Faculdade de Medicina Veterinária de Araçatuba (FMVA), Universidade Estadual Paulista (UNESP), Araçatuba, SP, Brasil.

${ }^{3}$ Departamento de Clínica, Cirurgia e Reprodução Animal, Faculdade de Medicina Veterinária de Araçatuba (FMVA), Universidade Estadual Paulista (UNESP), Araçatuba, SP, Brasil.

\begin{abstract}
This article evaluated the vital parameters, blood gas measurements, cortisol values and radiological findings of goat kids born at term and prematurely during the first 48 hours of life. For this purpose, 24 kids from 24 goats were used and assigned to groups as follows: Group I, eight kids born through cesarean sections performed at 149 days of gestation; Group II, eight kids born through cesarean sections performed at 143 days of gestation; Group III, eight kids born through cesarean sections performed at 143 days of gestation, whose mothers received $20 \mathrm{mg}$ of dexamethasone. Group I had lower heart rate values than the other groups at 60 minutes after birth. In terms of temperature, there was no difference between the groups. The pH values were reduced shortly after birth, rising at 24 and 48 hours in all animals studied. In terms of the cortisol levels, the values increased significantly at birth (M0), with the highest values obtained in animals in group II. These values decreased at 48 hours after birth in the evaluated goats. The animals belonging to group I showed better radiographic aspects, and throughout the 48 hours of evaluation, all newborns exhibited adequate respiratory adaptation. It can be concluded that antenatal dexamethasone administered at 143 days of gestation did not influence neonatal viability, metabolic or radiographic parameters. The metabolic changes found are consistent with the extrauterine adaptation period that animals in this stage of life.
\end{abstract}

Key words: lung maturity, blood gas analysis, neonates, goats.

Avaliação clínica e laboratorial de cabritos prematuros com e sem corticoterapia antenatal

RESUMO: O presente artigo teve como objetivo avaliar os parâmetros vitais, hemogasométricos, valores de cortisol e os achados radiológicos, de cabritos nascidos a termo e prematuros, durante as primeiras 48 horas de vida. Para tanto, foram utilizados 24 cabritos oriundos de 20 cabras, distribuidos nos grupos: grupo I: oito cabritos nascidos por meio de cesarianas realizadas aos 149 dias de gestação; grupo II: oito cabritos nascidos por meio de cesarianas realizadas aos 143 dias de gestação; grupo III: oito cabritos nascidos por meio de cesarianas realizadas aos 143 dias de gestação, cujas mães receberam $20 \mathrm{mg}$ de dexametasona. O grupo I apresentou valores mais baixos de frequência cardíaca quando comparados aos demais grupos aos 60 minutos após o nascimento. Em relação à temperatura, não houve diferença entre os grupos nos momentos avaliados. Os valores de pH apresentaram-se diminuídos logo após o nascimento, vindo a elevar-se nos momentos 24 e 48 horas em todos animais estudados. Em relação à análise dos niveis de cortisol, os valores aumentaram de forma significativa no (M0), com os maiores valores obtidos nos animais do grupo II. Esses valores decresceram às 48 horas após o nascimento nos cabritos avaliados. Os animais pertencentes ao grupo I demonstraram melhores aspectos radiográficos, sendo que, ao longo das 48 horas de avaliação, todos os recém-nascidos possuíam adequada adaptação respiratória. Conclui-se que a dexametasona antenatal realizada aos 143 dias de gestação não exerceu influência sobre a viabilidade neonatal, parâmetros metabólicos e radiográficos. As alterações metabólicas encontradas são condizentes com o periodo de adaptação extrauterina que animais nessa fase de vida enfrentam.

Palavras-chave: maturidade pulmonar, hemogasometria, neonatos, caprinos.

\section{INTRODUCTION}

After birth, a critical period called the "transition period" begins, when the neonate has to adapt from intrauterine to extrauterine life. In this phase, the body systems promote physiological adjustments considered crucial for the neonate. In premature newborns, this challenge is even greater since they have difficulty inflating their lungs due to insufficient synthesis of surfactant, which is usually 
released into the alveolar spaces and tracheal fluid at the end of the gestation period (AINSWORTH, 2005). Pulmonary immaturity causes respiratory distress syndrome (BLEUL, 2009), and these animals may present more intense respiratory and metabolic acidosis than those born at a physiological gestational age (FEITOSA et al., 2017).

Corticosteroids are known to accelerate fetal lung maturation and surfactant production (ROONEY et al., 1976). For this reason, antenatal glucocorticoid therapy is routinely performed to reduce the incidence of respiratory distress syndrome in premature kids (BALLARD et al., 1997). Several studies have been conducted on sheep, as this species also serves as a research model for humans, to establish a protocol for the use of corticosteroids aimed at fetal lung maturation (IKEGAMI et al., 1997; MILLER et al., 2009; PHILIP et al., 1997; LIGGINS, 1969; SCHMIDT et al., 2018). In fact, the effectiveness of this therapy has already been proven; however, the dose used and duration of treatment, as well as the effects involved, are still a subject of research.

Given the scarcity of data in the literature, the physical and metabolic changes in premature kids and the establishment of glucocorticoid protocols for pulmonary maturation requires further study. This study evaluated the influence of antenatal dexamethasone on perinatal viability and metabolic and radiographic parameters in premature kids.

\section{MATERIALS AND METHODS}

Three experimental groups were formed with 24 kids from 20 Boer goats. Group 1 (control) comprised eight kids born via $\mathrm{C}$-sections performed at 149 days of gestation, group 2 comprised eight kids born via C-sections performed at 143 days of gestation, and group 3 comprised eight kids born via $\mathrm{C}$-sections performed at 143 days of gestation, whose mothers received $20 \mathrm{mg}$ of dexamethasone (Azium ${ }^{\circledR}$, Schering-Plough) intramuscularly 36 hours before elective surgeries. All females were mated by natural mating, and mating identification was performed by observation. Gestation time was verified and monitored by ultrasonography.

The kids were monitored and fed with colostrum if they did not voluntarily suckle within 2 hours of birth. Colostrum was supplied in bottles, in a volume corresponding to $10 \%$ of the animal live weight, at 2 hours of age and between 10 and 12 hours after the first feeding. Animals that presented with hypothermia and hypoxia were assisted with the use of heating pads or thermal blankets, and a bag valve mask for ventilation, respectively.

All animals of the different groups had their rectal temperature (RT) measured, as well as their heart rate (HR) and respiratory rate (RR) at birth (MOh) and at 15 (M15min) minutes, 30 (M30min) minutes, 60 (M60min) minutes, 24 (M24h) hours, and 48 (M48h) hours of life. Blood samples were collected from the jugular vein of all animals using syringes containing calcium lithium heparin (80 IU of heparin) and stored in tubes without anticoagulant for blood gas and cortisol analysis. In addition, these evaluations were performed using samples collected from the umbilical cord (Muc). Blood gas analysis was performed from the heparinized blood samples within 15 minutes after collection, as recommended by LISBOA et al. (2002). The measurement of $\mathrm{pH}$, partial pressure of carbon dioxide $\left(\mathrm{pCO}_{2}\right)$, bicarbonate $\left(\mathrm{HCO}_{3}\right)$ and base excess/ deficit (BE) levels was performed in a portable electronic clinical analyzer (i-Stat ${ }^{\circledR}$ Portable Clinical Analyzer), using specific cartridges (EG7+ Cartridge), according to the manufacturer's recommendations. Blood serum was analyzed using a radio immunoenzymatic test to determine blood cortisol levels. Chest radiographic examinations were performed at $\mathrm{M} 0 \mathrm{~h}$, $\mathrm{M} 24 \mathrm{~h}$, and M48h using fixed X-ray equipment in the lateral decubitus position. Data were analyzed using repeated-measures analysis of variance, using the MIXED procedure of SAS (Statistical Analysis System) and covariance structure defined by Akaike information criterion. The multiple comparisons of means were performed using LSMEANS (Least Squares Means), adjusted by Tukey's test. The values of the variables (tables with the medians) were analyzed using the Kruskal-Wallis test to compare the groups at each time point, and the Friedman test to compare the times for each group, followed by Dunn's multiple comparisons test. The ANOVA test was used to compare between the times within each group in some variables and to analyze the repeated measures in time. The level of significance adopted was $5 \%$. Statistical analyses were performed using the SAS program (SAS Institute Inc. The SAS System, release 9.3. SAS Institute Inc., Cary:NC, 2016).

The experiment was approved by the animal ethics committee (CEUA) of the School of Veterinary Medicine of Araçatuba (FMVA), under protocol No. 2014-00473.

\section{RESULTS AND DISCUSSION}

According to EDMONDSON et al. (2012), for newborn viability, the minimum gestational time 
for induced birth should be 144 days. However, no mortality was observed even in those animals that were not under the influence of corticoid therapy. The physiological gestational time of the animals in the present study may have influenced this result since factors such as breed, reproductive season, weight of the kids and number of fetuses can interfere in the gestation time (MELLADO et al., 2000). Therefore, the gestational period of 143 days for these animals may not have negatively influenced pulmonary maturation, a fact that can be confirmed by the clinical and laboratorial findings.

The HR remained stable throughout the evaluated periods in all groups, and dexamethasone did not influence this variable (Table 1). Although, no significant difference was observed between the time points of all evaluated groups, the mean HR was above the normal range for the species, at 95$120 \mathrm{bpm}$ (FEITOSA, 2020). A progressive increase in $\mathrm{HR}$ is expected in the first moments of life, due to the fact that animals in this phase of life present low systolic volume at birth, making the heart pump a higher volume of blood to the vascular system, which presents high elasticity and peripheral resistance (PICCIONE et al., 2007). The HR peak in G1 occurred at 15 minutes of life, unlike G2 where it was only observed at 60 minutes. This dynamic was also observed in lambs and is probably related to the fact that hemodynamic changes in premature animals are attenuated compared to animals born at term, causing a more gradual increase in HR (PADBURY et al., 1985).

Premature lambs may present lower RR values, especially when born via $\mathrm{C}$-section. This occurs because these animals have difficulty initiating respiratory movements, responsible for the initiation of ventilation and establishment of functional residual capacity (ÁVILA et al., 2014). The RR did not differ in terms of the moments of the groups, or in the moments within the same group (Table 2). The values obtained are associated with the animals' stage of life, suggesting that birth at 143 days may not cause significant changes in the respiratory system in goats. This can be confirmed by the $\mathrm{pH}$ and $\mathrm{pCO}_{2}$ values reported in this group, which did not differ from the group of animals born in the physiological gestational period for the species.

Only one animal belonging to group 1 and another to group 2 required ventilatory assistance at birth, being intubated and kept ventilated by neonatal manual respirator. However, these animals showed adequate vital parameters up to 30 minutes after birth and were perfectly adapted at the end of the 48 hours of assessment due to the increased blood flow and oxygen levels, with a consequent decrease in circulating carbon dioxide levels (FEITOSA, 2011). Animals that required ventilatory assistance were born underweight and; consequently, with lower vitality, factors that may have contributed to this clinical presentation.

In all animals, auscultation of the pulmonary fields showed, to varying degrees, slight to moderate respiratory noise resulting from the presence of fluid in the airways, explained by the fact these animals were born via C-section. RT did not differ in the groups over the evaluated time points (Table 3). The use of antenatal dexamethasone was correlated with a substantial improvement in thermoregulation in premature lambs by increasing plasma concentrations of thyroid hormone (CLARKE

Table 1 - Median (Md), minimum (min) and maximum (max) heart rate values (HR) in kids born at term at 149 days (Group 1), premature C-section at 143 days (Group 2), premature C-section at 143 days after maternal dexamethasone administration (Group 3 ) in the first 48 hours of life.

\begin{tabular}{|c|c|c|c|c|c|c|c|c|c|c|}
\hline \multirow[t]{3}{*}{ Variable } & \multirow[t]{3}{*}{ Moments } & \multicolumn{9}{|c|}{ 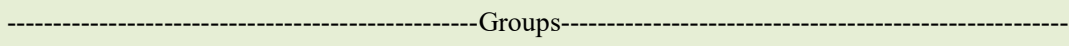 } \\
\hline & & \multicolumn{3}{|c|}{-------------------1 ------------------- } & \multicolumn{3}{|c|}{----------------2------------- } & \multicolumn{3}{|c|}{----------------------3----------------- } \\
\hline & & $\mathrm{n}$ & $\mathrm{Md}$ & Min-Max & $\mathrm{n}$ & $\mathrm{Md}$ & Min-Max & $\mathrm{n}$ & Md & Min-Max \\
\hline \multirow{6}{*}{$\begin{array}{l}\text { HR } \\
(\mathrm{bpm})\end{array}$} & $\mathrm{M}_{0}$ & 8 & 126 & $72-200$ & 8 & 158 & $120-180$ & 8 & 160 & $76-160$ \\
\hline & $\mathrm{M}_{15}$ & 8 & 164 & $116-200$ & 8 & 150 & $112-176$ & 8 & 160 & $100-180$ \\
\hline & $\mathrm{M}_{30}$ & 8 & 142 & $112-160$ & 8 & 164 & $120-180$ & 8 & 160 & $136-172$ \\
\hline & $\mathrm{M}_{60}$ & 8 & $146^{\mathrm{A}}$ & $116-160$ & 8 & $164^{\mathrm{B}}$ & $160-176$ & 8 & $160^{\mathrm{B}}$ & $132-168$ \\
\hline & $\mathrm{M}_{24}$ & 8 & 142 & $108-184$ & 8 & 160 & $136-172$ & 8 & 160 & $144-180$ \\
\hline & $\mathrm{M}_{48}$ & 8 & $136^{\mathrm{A}}$ & 80-192 & 8 & $174^{\mathrm{B}}$ & $160-176$ & 8 & $160 A^{B}$ & $160-180$ \\
\hline
\end{tabular}

Medians followed by different letters, upper case in the row and lower case in the column, differ by the Kruskal-Wallis test and Friedman test, followed by Dunn's post-test $(\mathrm{P}<0.05)$. The absence of letters implies that there is no statistical difference. 
Table 2 - Mean $(\bar{x})$ and standard deviation (S) of respiratory rate values (RR) of kids born via C-section at 149 days (Group 1), premature C-section at 143 days (Group 2), and premature C-section at 143 days after maternal dexamethasone administration (Group 3), in the first 48 hours of life.

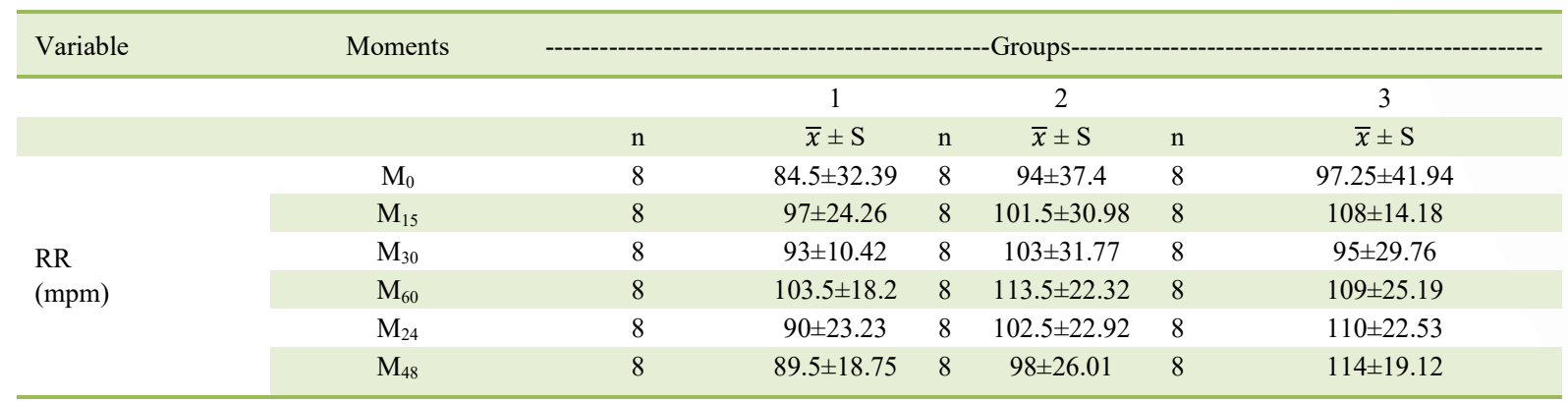

The ANOVA test was used between groups and ANOVA of repeated measures in time was used between times within each group, followed by Tukey post-test $(\mathrm{P}<0.05)$. The absence of letters implies that there is no statistical difference.

et al., 1998). This study did not identify this effect; however, other factors, such as ambient temperature, may directly influence the magnitude of this response (CLARKE et al., 1998). At birth, RT was compatible with the values referenced for the species, but after 1 hour of life, all groups showed a significant decrease in values. This can be explained by the increasing $\mathrm{RR}$ in an attempt to eliminate excess carbon dioxide produced and correct the acid-base balance (GUYTON \& HALL, 2002; ROBERTSHAW, 2006).

All animals presented clear pink mucous membranes at all the time points evaluated. SPRENG et al. (2004) reported that healthy neonates should present intense pinkish mucous membranes; when cyanotic, they signal severe hypoxemia. This result confirmed the hypothesis that goats born at 143 days of gestation can be viable and present pulmonary maturation.

In all groups, the $\mathrm{pH}$ in Muc was higher than that atM0h (Table 4). This occurs because the rupture of the umbilical cord causes anaerobic glycolysis, which occurs in the tissue of low circulation during the transition between the supply of oxygen in the placenta and the establishment of respiratory function (VAALA \& HOUSE, 2006). In this study, the $\mathrm{pH}$ decreased soon after birth (M0h), increasing to values close to the physiological ones (MEYER et al. 1995; THRALL, 2006) at M24h, with stabilization at M48h. Blood samples collected from the umbilical cord at birth and at 15,30 and 60 minutes of life demonstrated the occurrence of acidemia. Calves with $\mathrm{pH}<7.2$ are considered acidotic, with

Table 3 - Median $(\mathrm{Md})$, minimum ( $\min )$ and maximum $(\max )$ temperature values $\left({ }^{\circ} \mathrm{C}\right)$ of kids born at term at 149 days $(\mathrm{Group} 1)$, premature C-section at 143 days (Group 2), premature C-section at 143 days after administration of dexamethasone (Group $3)$, in the first 48 hours of life.

\begin{tabular}{|c|c|c|c|c|c|c|c|c|c|c|}
\hline \multirow[t]{3}{*}{ Variable } & \multirow[t]{3}{*}{ Moments } & \multicolumn{9}{|c|}{ 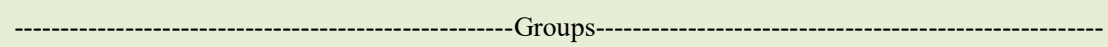 } \\
\hline & & \multicolumn{3}{|c|}{ 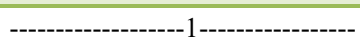 } & \multicolumn{3}{|c|}{ 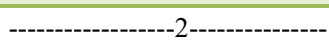 } & \multicolumn{3}{|c|}{----------------------3---------------- } \\
\hline & & $\mathrm{n}$ & Md & Min-Max & $\mathrm{n}$ & Md & Min-Max & $\mathrm{n}$ & Md & Min-Max \\
\hline \multirow{6}{*}{$\begin{array}{l}\text { Temperature } \\
\left({ }^{\circ} \mathrm{C}\right)\end{array}$} & $\mathrm{M}_{0}$ & 8 & $38.15^{\mathrm{b}}$ & $36.1-39.2$ & 8 & $39^{\mathrm{a}}$ & $37.5-39.5$ & 8 & $38.7^{\mathrm{a}}$ & $37.5-39.3$ \\
\hline & $\mathrm{M}_{15}$ & 8 & 36.5 & $35.3-38$ & 8 & $37.2^{\mathrm{b}}$ & $34.7-39.2$ & 8 & $37.8^{\mathrm{b}}$ & $34.2-38.3$ \\
\hline & $\mathrm{M}_{30}$ & 8 & $36.05^{\mathrm{a}}$ & $35.10-37.3$ & 8 & $37.15^{\mathrm{b}}$ & $34.9-38.6$ & 8 & $37.3^{b}$ & $35-38.3$ \\
\hline & $\mathrm{M}_{60}$ & 8 & $36.75^{\mathrm{a}}$ & $33.5-37.3$ & 8 & 37.15 & $35.6-39.2$ & 8 & 37.55 & $36.1-38.8$ \\
\hline & $\mathrm{M}_{24}$ & 8 & $38.2^{\mathrm{b}}$ & $37.7-38.7$ & 8 & 38.2 & $35.6-38.9$ & 8 & 38.35 & $37.8-39.1$ \\
\hline & $\mathrm{M}_{48}$ & 8 & $38.75^{\mathrm{b}}$ & $37.6-39$ & 8 & 37.35 & $37.2-39.1$ & 8 & 38.25 & $37.9-38.9$ \\
\hline
\end{tabular}

Medians followed by different letters, upper case in the row and lower case in the column, differ by the Kruskal-Wallis test and Friedman test, followed by Dunn 1 s post-test $(\mathrm{Pp}<0.05)$. The absence of letters implies that there is no statistical difference.

Ciência Rural, v.52, n.7, 2022. 
Table 4 - Median (Md), minimum ( $\mathrm{min}$ ) and maximum ( $\max$ ) potential hydrogen values $(\mathrm{pH})$, partial pressure of carbon dioxide (pCO $\mathrm{p}_{2}$ ), partial pressure of oxygen $\left(\mathrm{pO}_{2}\right)$, total oxygen saturation $\left(\mathrm{sO}_{2}\right)$, and venous blood base excess/deficit of kids born via C-section at 149 days (Group 1), premature C-section at 143 days (Group 2), and premature C-section at 143 days after maternal dexamethasone administration (Group 3), in the first 48 hours of life.

\begin{tabular}{|c|c|c|c|c|c|c|c|c|c|c|}
\hline \multirow[t]{3}{*}{ Variable } & \multirow[t]{3}{*}{ Moments } & \multicolumn{9}{|c|}{ 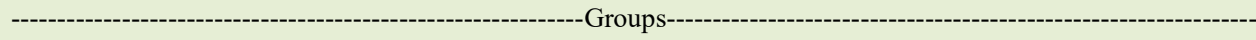 } \\
\hline & & \multicolumn{3}{|c|}{----------------------1------------------- } & \multicolumn{3}{|c|}{------------------------'------------------ } & \multicolumn{3}{|c|}{------------------3-------------- } \\
\hline & & $\mathrm{n}$ & Md & Min-Max & $\mathrm{n}$ & Md & Min-Max & $\mathrm{n}$ & Md & Min-Max \\
\hline \multirow{7}{*}{$\mathrm{pH}$} & $\mathrm{M}_{\mathrm{uc}}$ & 8 & $7.25^{\mathrm{Aa}}$ & $7.18-7.36$ & 8 & $7.3^{\mathrm{ABa}}$ & $7.25-7.37$ & 8 & $7.33^{\mathrm{Ba}}$ & $7.28-7.4$ \\
\hline & $\mathrm{M}_{0}$ & 8 & $7.12 \mathrm{bc}$ & $6.81-7.23$ & 8 & $7.14^{\mathrm{bc}}$ & $7.06-7.21$ & 8 & $7.18^{\mathrm{bc}}$ & $6.88-7.25$ \\
\hline & $\mathrm{M}_{15}$ & 8 & $7.17 \mathrm{c}$ & $6.89-7.24$ & 8 & $7.18^{\mathrm{c}}$ & $7.03-7.23$ & 8 & $7.22^{\text {bce }}$ & $6.85-7.29$ \\
\hline & $\mathrm{M}_{30}$ & 8 & $7.18^{\mathrm{ce}}$ & $7.04-7.23$ & 8 & $7.21^{\mathrm{ce}}$ & $7.02-7.25$ & 8 & 7.26 & $6.99-7.33$ \\
\hline & $\mathrm{M}_{60}$ & 8 & 7.18 & $6.91-7.25$ & 8 & 7.24 & $6.95-7.28$ & 8 & 7.255 & 7.07-7.34 \\
\hline & $\mathrm{M}_{24}$ & 8 & $7.32^{\mathrm{d}}$ & 7.31-7.39 & 8 & $7.32^{\mathrm{de}}$ & $7.16-7.43$ & 8 & $7.36^{\mathrm{d}}$ & $7.25-7.4$ \\
\hline & $\mathrm{M}_{48}$ & 8 & $7.33^{\mathrm{de}}$ & $7.28-7.38$ & 8 & $7.35^{\mathrm{d}}$ & $7.28-7.39$ & 8 & $7.30^{\mathrm{de}}$ & $7.2-738$ \\
\hline \multirow{7}{*}{$\begin{array}{l}\mathrm{pCO}_{2} \\
(\mathrm{mmHg})\end{array}$} & $\mathrm{M}_{\mathrm{uc}}$ & 8 & $53.95^{\mathrm{a}}$ & $42.1-66.1$ & 8 & $47,9^{\mathrm{a}}$ & $45.1-53.7$ & 8 & $47.25^{\mathrm{a}}$ & $42.7-58.7$ \\
\hline & $\mathrm{M}_{0}$ & 8 & $72.5^{\mathrm{bc}}$ & $61.8-110.6$ & 8 & $67.4^{\mathrm{bc}}$ & $63.8-76.5$ & 8 & $64,3^{b}$ & $60.5-130$ \\
\hline & $\mathrm{M}_{15}$ & 8 & 62.15 & $54.2-84.1$ & 8 & $60.45^{\mathrm{ce}}$ & $53.1-69.1$ & 8 & $62.35^{\mathrm{b}}$ & $55.2-79.5$ \\
\hline & $\mathrm{M}_{30}$ & 8 & 60.35 & $48.2-64.7$ & 8 & 56.95 & $48.8-66.8$ & 8 & 54.75 & $50.3-66.5$ \\
\hline & $\mathrm{M}_{60}$ & 8 & 63.25 & $46.5-70$ & 8 & $55.9^{\mathrm{ce}}$ & $48.3-75.6$ & 8 & 55.35 & $50.5-64.3$ \\
\hline & $\mathrm{M}_{24}$ & 8 & $51.95^{\mathrm{d}}$ & $48.5-56.6$ & 8 & $46.2^{\mathrm{de}}$ & $41.8-68.7$ & 8 & 55.1 & $46.3-69.7$ \\
\hline & $\mathrm{M}_{48}$ & 8 & $52.7^{\mathrm{d}}$ & $43.7-69.4$ & 8 & $47.6^{\mathrm{d}}$ & $40.9-59.6$ & 8 & 55.55 & $46-64.1$ \\
\hline \multirow{7}{*}{$\begin{array}{l}\mathrm{tCO}_{2} \\
(\%)\end{array}$} & $\mathrm{M}_{\mathrm{uc}}$ & 8 & 24.5 & $20.9-27$ & 8 & 22.2 & $19.3-23.3$ & 8 & $22.7^{\mathrm{a}}$ & $19.9-25.4$ \\
\hline & $\mathrm{M}_{0}$ & 8 & 23.45 & $20-28$ & 8 & 22.85 & $18.6-24.5$ & 8 & $22.4^{\mathrm{a}}$ & $17.2-26.5$ \\
\hline & $\mathrm{M}_{15}$ & 8 & $23.95^{\mathrm{a}}$ & $18-26$ & 8 & $21.3^{\mathrm{a}}$ & $17.9-23$ & 8 & 22.75 & $13.8-27.2$ \\
\hline & $\mathrm{M}_{30}$ & 8 & $25^{\mathrm{a}}$ & $19-26.6$ & 8 & 22.25 & $18.5-48.8$ & 8 & 22.7 & $13-28.7$ \\
\hline & $\mathrm{M}_{60}$ & 8 & $24.6^{\mathrm{a}}$ & $16-29$ & 8 & 23.05 & $18.7-46.8$ & 8 & 23.35 & $21-31.4$ \\
\hline & $\mathrm{M}_{24}$ & 8 & $27.05^{\mathrm{AB}}$ & $23-32$ & 8 & $23.6^{\mathrm{A}}$ & $21.5-27.1$ & 8 & $28.9^{\mathrm{Bb}}$ & $25.4-33.1$ \\
\hline & $\mathrm{M}_{48}$ & 8 & $26.95^{\mathrm{b}}$ & $22.9-38$ & 8 & $24.9 \mathrm{~b}$ & $21.4-27.3$ & 8 & 25.3 & $22.1-28$ \\
\hline \multirow{7}{*}{$\begin{array}{l}\mathrm{BE} \\
(\mathrm{mmol} / \mathrm{L})\end{array}$} & $\mathrm{M}_{\mathrm{uc}}$ & 8 & -3.55 & $-6-(-1)$ & 8 & -2.65 & $-5.3-(-0.4)$ & 8 & -0.65 & $-4.1-2.8$ \\
\hline & $\mathrm{M}_{0}$ & 8 & $-4.7^{\mathrm{a}}$ & $-16-(-3)$ & 8 & $-6.25^{\mathrm{a}}$ & $-10.7-(-3)$ & 8 & $-5.45^{\mathrm{a}}$ & $-23.9-(0.1)$ \\
\hline & $\mathrm{M}_{15}$ & 8 & $-5.45^{\mathrm{ac}}$ & $-16-(-2.8)$ & 8 & $-5.7^{\mathrm{a}}$ & $-12.1-(-3.4)$ & 8 & $-4.4^{\mathrm{ac}}$ & $-21.2-0.8$ \\
\hline & $\mathrm{M}_{30}$ & 8 & $-5^{\mathrm{ac}}$ & $-14-(3.6)$ & 8 & $-5.05^{\mathrm{ac}}$ & $-13.1-(-2.8)$ & 8 & -3.95 & $-18.5-3.1$ \\
\hline & $\mathrm{M}_{60}$ & 8 & $-5^{\mathrm{a}}$ & $-19-(-2)$ & 8 & -3.65 & $-11.6-(15)$ & 8 & -4.35 & $-13.6-7$ \\
\hline & $\mathrm{M}_{24}$ & 8 & $1.1^{\mathrm{ABb}}$ & $-4-(6)$ & 8 & $-1.6^{\mathrm{Abc}}$ & $-5.9-3.5$ & 8 & $3.4^{\mathrm{Bb}}$ & $1.4-8.8$ \\
\hline & $\mathrm{M}_{48}$ & 8 & $2.05^{\mathrm{bc}}$ & $-1.9-(6)$ & 8 & $1.1^{\mathrm{b}}$ & $-3.3-4.3$ & 8 & $-0.55^{\mathrm{bc}}$ & $-3-2.9$ \\
\hline
\end{tabular}

Medians followed by different letters, upper case in the row and lower case in the column, differ by the Kruskal-Wallis test and Friedman test, followed by Dunn's post-test $(\mathrm{P}<0.05)$. The absence of letters implies that there is no statistical difference.

reduced vitality and survival rates (BLEUL \& GÖTZ, 2013). In this study, the animals of all groups showed $\mathrm{pH}$ values below those at birth; however, no increase in mortality was observed in the evaluation period. Prematurity also did not reduce $\mathrm{pH}$ values, since the kids born at 143 days of gestation showed similar values to those born at the physiological gestational age. Although, group 1 presented lower $\mathrm{pH}$ than group 3 at M0h, it is not possible to confirm the effect of antenatal dexamethasone therapy on this variable, since group 3 did not differ from group 2.

In all groups, the $\mathrm{pCO}_{2}$ was higher at M0h in relation to Muc;, and subsequently, the values decreased but were still above reference values. Prematurity is associated with more intense metabolic and respiratory acidosis (FEITOSA et al., 2017). However, in this study, the acid-base disorders reported were consistent with those observed in animals born at term, indicating that the interruption of pregnancy at 143 days in goats does not result in significant changes in acid-base balance.

The TCO2 values obtained were lower at 60 minutes after birth than the reference values for the species, which ranged from 25.6 to $29.6 \mathrm{mmol} / \mathrm{L}$ (KANEKO et al., 2008). In the evaluations at 24 and 48 hours of life, the values were within the reference 
range, except for the animals belonging to group 2 . This adequacy in the values suggested stabilization of the metabolic presentation. Respiratory acidosis due to hypercapnia results in increased reabsorption of bicarbonate by the kidneys. Normal levels of bicarbonate may indicate its use for buffering excess carbon dioxide, forming carbonic acid (VANNUCCHI et al., 2012).

Except in group 2, bicarbonate concentrations were minimal in the Muc, presenting gradual increase with the highest values at 24 and 48 hours of life (Table 5). This increase occurs as a compensatory effect to the acidemia, through the chemical buffering of the excess of hydrogen ions (GUYTON \& HALL, 2002). A similar effect was described in premature lambs born under the effect of antenatal corticotherapy (ZOLLER et al., 2015). In premature kids, dexamethasone had a positive influence on bicarbonate concentration at M24h. In lambs, dexamethasone did not produce the same result (FEITOSA et al., 2017).

All groups had a significant increase at M24h as for the BE (Table 4). Even at Muc and $\mathrm{M} 0 \mathrm{~h}$, the values; although, lower than those at M24h, were within the limits of variability, set from -4 to +4 (HASKINS, 1977). In calves, the physiological acid-base imbalance immediately after birth is solved in about 2 hours in the case of metabolic acidosis and around 24 to 48 hours for respiratory acidosis (VARGA et al., 2001; UYSTEPRUYST, 2006). This condition may occur due to the physiological reversal of the acidemia suffered during birth, due to the beginning of the respiratory activity and the renal filtration mechanism, obeying the new circulatory and respiratory pattern established by the organism (HASKINS, 1977; BENESI, 1993). The kids showed a mixed acidosis picture soon after birth, but these parameters regularized in the first 24 hours of life, showing that animals born via $\mathrm{C}$-section tended to develop a more accentuated acidosis presentation than those born via normal birth, but with total adaptation by the end of the first day of life. Premature kids born at 143 days of gestation behaved similarly to those born at 149 days in terms of adaptation and viability.

Cortisol concentrations were higher in groups 1 and 2 than in group 3 during the first hour of life (Table 6). This is possibly due to the elevation of this hormone in the final stages of gestation (HAFEZ, 2003). In group 3, the lower values found may be related to fetal and maternal suppression of the adrenal cortex by corticoids, since they inhibit the release of ACTH in the pituitary. According to BALLARD \& BALLARD (1995), fetal cortisol concentration measured in blood collected from the umbilical cord decreased by $50 \%$ after maternal corticotherapy. In groups 1 and 2, cortisol levels significantly decreased at 48 hours compared to the first hour of life, showing the adaptation of neonates to the extrauterine phase. HOYER et al. (1990) showed an increase in the plasma concentration of cortisol in bovine neonates in the first 6 days of life, especially in animals that suffered asphyxia during the perinatal period, and this response was interpreted as a reflex to stress. This study did not find persistent elevation of cortisol levels even in animals born prematurely.

In general, the radiographic analysis of all animals soon after birth indicated the presence

Table 5 - Mean $(\bar{x})$ and standard deviation $(\mathrm{S})$ of venous blood bicarbonate $\left(\mathrm{HCO}_{3}\right)$ values of kids born via C-section at 149 days $(\mathrm{Group}$ 1 ), premature C-section at 143 days (Group 2), and premature C-section at 143 days after maternal dexamethasone administration (Group 3), in the first 48 hours of life.

\begin{tabular}{|c|c|c|c|c|c|c|c|}
\hline \multirow[t]{3}{*}{ Variable } & \multirow[t]{3}{*}{ Moments } & \multicolumn{6}{|c|}{----------------------------------------------------Groups--' } \\
\hline & & & 1 & & 2 & & 3 \\
\hline & & $\mathrm{n}$ & $\bar{x} \pm \mathrm{S}$ & $\mathrm{n}$ & $\bar{x} \pm \mathrm{S}$ & $\mathrm{n}$ & $\bar{x} \pm \mathrm{S}$ \\
\hline \multirow{7}{*}{$\begin{array}{l}\mathrm{HCO}_{3} \\
(\mathrm{mmol} / \mathrm{L})\end{array}$} & $\mathrm{M}_{\mathrm{uc}}$ & 8 & $23.34 \pm 1.38^{\mathrm{a}}$ & 8 & $23.01 \pm 1.51$ & 8 & $24.6 \pm 2.29^{\mathrm{a}}$ \\
\hline & $\mathrm{M}_{0}$ & 8 & $22.51 \pm 3.39^{\mathrm{a}}$ & 8 & $22.36 \pm 2.29$ & 8 & $22.69 \pm 4.14$ \\
\hline & $\mathrm{M}_{15}$ & 8 & $22.23 \pm 3.51^{\mathrm{a}}$ & 8 & $21.65 \pm 1.91$ & 8 & $22.93 \pm 5.12$ \\
\hline & $\mathrm{M}_{30}$ & 8 & $21.85 \pm 2.95^{\mathrm{a}}$ & 8 & $21.66 \pm 2.82$ & 8 & $23.21 \pm 5.49$ \\
\hline & $\mathrm{M}_{60}$ & 8 & $22.25 \pm 4.19^{\mathrm{ac}}$ & 8 & $23.25 \pm 5.1$ & 8 & $24.04 \pm 5.38$ \\
\hline & $\mathrm{M}_{24}$ & 8 & $27.93 \pm 2.46^{\mathrm{ABbc}}$ & 8 & $25.71 \pm 1.77^{\mathrm{A}}$ & 8 & $30.19 \pm 2.58^{\mathrm{Bb}}$ \\
\hline & $\mathrm{M}_{48}$ & 8 & $27.99 \pm 3.23^{\mathrm{b}}$ & 8 & $26.15 \pm 3.06$ & 8 & $26.48 \pm 1.89$ \\
\hline
\end{tabular}

Means followed by different letters, upper case in the row and lower case in the column, differ by ANOVA and ANOVA of repeated measures in time, followed by Tukey's post-test $\mathrm{Pp}<0.05$ ). The absence of letters implies that there is no statistical difference. 
Table 6 - Median (med), minimum (min) and maximum (max) cortisol values (in nmol/L), of kids born at 149 days of gestation (Group 1), via C-section at 143 days of gestation (Group 2), C-section at 143 days of gestation after maternal dexamethasone administration (Group 3), in the first 48 hours of life.

\begin{tabular}{|c|c|c|c|c|c|c|c|c|c|}
\hline \multirow[t]{3}{*}{ Moments } & \multicolumn{9}{|c|}{ 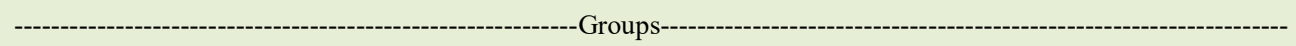 } \\
\hline & \multicolumn{3}{|c|}{-----------------------1 1--------------------- } & \multicolumn{3}{|c|}{ |-----------------------2------------------- } & \multicolumn{3}{|c|}{-------------------------3----------------- } \\
\hline & $\mathrm{n}$ & Md & Min - Max & $\mathrm{n}$ & Md & Min - Max & $\mathrm{n}$ & Md & Min - Max \\
\hline $\mathrm{M}_{\mathrm{uc}}$ & 8 & $63.4^{\mathrm{Aba}}$ & 47-97.42 & 8 & $119.9^{\text {Aac }}$ & $34.6-252.4$ & 8 & $34.95^{\mathrm{Ba}}$ & 6.3-1.4 \\
\hline $\mathrm{M}_{0}$ & 8 & $132.9^{\mathrm{A}}$ & $119.6-163.1$ & 8 & $214.9^{\mathrm{A}}$ & $99.4-316.2$ & 8 & $62.5^{\mathrm{B}}$ & $5.9-114.9$ \\
\hline $\mathrm{M}_{15}$ & 8 & $150.1^{\mathrm{AB}}$ & $126.3-213.4$ & 8 & $227.7^{\mathrm{Ab}}$ & $90.8-354.9$ & 8 & $81.4^{\mathrm{Bb}}$ & $25.4-195.4$ \\
\hline $\mathrm{M}_{30}$ & 8 & $173.7^{\mathrm{Ab}}$ & $141.6-246$ & 8 & $226^{\mathrm{Ab}}$ & $97-358.3$ & 8 & $66.25^{\mathrm{B}}$ & $22.8-164$ \\
\hline $\mathrm{M}_{60}$ & 8 & $177.3^{\mathrm{Ab}}$ & $148-317.4$ & 8 & $248.4^{\mathrm{Abc}}$ & $134.7-451.9$ & 8 & $59.8^{\mathrm{B}}$ & $20.5-174.2$ \\
\hline $\mathrm{M}_{24}$ & 8 & 134.4 & $21.5-178.8$ & 8 & 107.3 & $43.4-382.1$ & 8 & $100.5^{\mathrm{b}}$ & 29.5-201.4 \\
\hline $\mathrm{M}_{48}$ & 8 & $53.1^{\mathrm{a}}$ & $23.9-89.9$ & 8 & $72.75^{\mathrm{a}}$ & $21.9-122.8$ & 8 & 59.75 & $44.7-100.5$ \\
\hline
\end{tabular}

Means followed by different letters, upper case in the row and lower case in the column, differ by ANOVA and ANOVA of repeated measures in time, followed by Tukey's post-test $\mathrm{Pp}<0.05)$, The absence of letters implies that there is no statistical difference,

of a slight increase in pulmonary radiopacity with a linear interstitial pattern located in the diaphragmatic lobes with the presence of rare air bronchograms, with integrity of the diaphragmatic domes and pleural and mediastinal spaces in most animals, compatible with the age and type of birth of the kids studied. The animals in group 1 showed better radiographic presentation; however, those in other groups also showed perfect adaptation regarding the absorption of liquid present in the alveoli throughout the 48 hours of evaluation. Since the animals were born via $\mathrm{C}$-section, the presence of subtle radiopacity and rare air bronchograms are not considered significant findings. Some animals belonging to the premature groups also presented slight radiopacity and rare bronchograms at 48 hours after birth, a fact that did not interfere in the adaptation and survival of these animals in the neonatal period.

\section{CONCLUSION}

This study showed that antenatal dexamethasone at 143 days of gestation had no influence on neonatal viability or metabolic and radiographic parameters in goat kids. The metabolic changes found are associated with the period of extra uterine adaptation that animals face in this phase of life.

\section{ACKNOWLEDGMENTS}

The authors would like to thank the São Paulo Research Foundation (Fapesp) for funding the project (2012/219678) and granting a scholarship to the first author (2012/219674). This study was financed in part by the Coordenação de
Aperfeiçoamento de Pessoal de Nível Superior - Brasil (CAPES) - Finance Code 001.

\section{DECLARATION OF CONFLICT OF INTEREST}

The authors declare no conflict of interest. The founding sponsors had no role in the design of the study; in the collection, analyses, or interpretation of data; in the writing of the manuscript, and in the decision to publish the results.

\section{AUTHOR CONTRIBUTIONS}

All authors contributed equally to the conception and writing of the manuscript. All authors critically reviewed the manuscript and approved the final version.

\section{REFERENCES}

AINSWORTH, S. B. Pathophysiology of neonatal respiratory distress syndrome: implications for early treatment strategies. Treatments in Respiratory Medicine, v.4, p.423-437, 2005. Available from: $<$ https://link.springer.com/article/10.2165\% 2F00151829-200504060-00006>. Accessed: May, 3, 2020. doi: 10.2165/00151829-200504060-00006.

ÁVILA, L. G. et al. Maternal glucocorticoid in vital parameters of full-term and preterm lambs Ciência Rural, v.44, n.6, p.11061112, 2014. Available from: <https://www.scielo.br/scielo. php? script $=$ sci arttext\&pid $=$ S0103-84782014000600025>. Accessed: May, 3, 2020. doi: 10.1590/S0103-84782014000600025.

BALLARD, P. L. et al. Glucocorticoid regulation of surfactant components in immature lambs 1997. American Journal of Physiology, v.273, n.5, p.1048-1057. Available from: $<$ https://journals. physiology.org/doi/full/10.1152/ajplung.1997.273.5.L1048?rfr $\mathrm{dat}=\mathrm{cr}$ pub ++0 pubmed $\&$ url ver $=$ Z39.88-2003\&rfr $\mathrm{id}=$ ori\%3Arid\%3Acrossref.org $>$. Accessed: May, 3, 2020. doi: 10.1152/ajplung.1997.273.5.L1048. 
BALLARD, P.; BALLARD, R. A. Scientific basis and therapeutic regimens for use of antenatal corticosteroids. American Journal Obstetrics and Gynecology, v.173, p.254, 1995. Available from: $<$ https://pubmed.ncbi.nlm.nih.gov/7631700/>. Accessed: May, 3, 2020. doi: 10.1016/0002-9378(95)90210-4.

BENESI, F. J. Síndrome asfixia neonatal nos bezerros: importância e avaliação crítica. Arquivos da Escola De Medicina Veterinária da Universidade Federal da Bahia, v.16, n.1, p.38-48, 1993. Available from: <https://repositorio.usp.br/item/000922048>. Accessed: May, 3, 2020.

BLEUL, U. Respiratory distress syndrome in calves. Veterinary Clinics of North America: Food Animal Practice, v.25, p.179193, 2009. Available from: <https://www.sciencedirect.com/ science/article/abs/pii/S0749072008000881?via\%3Dihub>. Accessed: May, 3, 2020. doi: 10.1016/j.cvfa.2008.10.002.

BLEUL, U.; GÖTZ, E. The effect of lactic acidosis on the generation and compensation of mixed respiratory-metabolic acidosis in neonatal calves. Veterinary Record, v.172, p.528, 2013. Available from: <https://veterinaryrecord.bmj.com/content/172/20/528>. Accessed: May, 3, 2020. doi: 10.1136/vr.101192.

CLARKE, L. et al. Influence of maternal dexamethasone administration on thermoregulation in lambs delivered by caesarean section. Journal of Endocrinology, v.156, p.307314, 1998. Available from: <https://joe.bioscientifica.com/view/ journals/joe/156/2/307.xml>. Accessed: May, 3, 2020. doi: 10.1677/joe.0.1560307.

EDMONDSON, M. A.; et al.,Theriogenology of Sheep and Goats. In: PUGH, D. G.; BAIRD, A. N. Sheep and goat medicine, 2 ed. Elsevier, Philadelphia, 2012, pp.150-230.

FEITOSA, F. L. F. Semiologia Veterinária - A Arte do Diagnóstico. Roca, 4 ed, 2020, 704.

FEITOSA, F. L. F. et al. Avaliação da vitalidade de bezerros nelores nascidos de partos normais ou distócicos. Ars Veterinaria, Jaboticabal, v.27, n.3, p.1-7, 2011. Available from: <http:// docplayer.com.br/55788072-Avaliacao-da-vitalidade-de-bezerrosnelores-nascidos-de partos-normais-ou-distocicos-1.html $>$. Accessed: May, 3, 2020.

FEITOSA, F. L. F. et al. Efeitos da corticoterapia materna nos valores hemogasométricos de cordeiros nascidos a termo e prematuros. Pesquisa Veterinária Brasileira, v.37, n.5, p.521-525, 2017. Available from: <https://www.scielo.br/scielo.php?pid=S0100736X2017000500521\&script $=$ sci abstract\&tlng $=$ pt $>$. Accessed: May, 3, 2020. doi: 10.1590/s0100-736x2017000500016.

GUYTON, A. C.; HALL, J. E. Tratado De Fisiologia Médica. Rio De Janeiro: Guanabara Koogan, 2002. p.973.

HAFEZ, E. S. E. Reprodução Animal. São Paulo: Manole, 2003, p.530.

HASKINS, S. C. An overview of acid-base physiology. Journal of the American Veterinary Medical Association, v.170, p.423-428, 1977. Available from: <https://pubmed.ncbi.nlm.nih.gov/14092/>. Accessed: May, 3, 2020.

HOYER, C. et al. Plasma Glucocorticoids concentrations in calves as an indicator of stress during parturition. American Journal of Veterinary Research., v.51, p.1882-1884, 1990. Available from: $<$ https://pubmed.ncbi.nlm.nih.gov/2240818/>. Accessed: May, 3, 2020.
IKEGAMI M. et al. Repetitive prenatal glucocorticoids improve lung function and decrease growth in preterm lambs. American Journal of Respiratory and Critical Care Medicine, v.156, p.178-184, 1997. Available from: <https://pubmed.ncbi.nlm. nih.gov/9230744/>. Accessed: Jul. 10, 2021. doi: 10.1164/ ajrccm.156.1.9612036.

KANEKO, J. J.; HARVEY, J. W.; BRUSS M. L. Clinical Biochemistry of Domestic Animals. New York: Academic Press, 2008. p. 928

LIGGINS, G. C. Premature delivery of fetal lambs infused with glucocorticoids. Journal of Endocrinology, v.45, p.515-523, 1969. Available from: <https://pubmed.ncbi.nlm. nih.gov/5366112/>. Accessed: Jul. 10, 2021. doi: 10.1677/ joe. 0.0450515 .

LISBOA, J. A. N. et al. Efeito da idade sobre o equilíbrio ácido básico de bezerras sadias no primeiro mês de vida. Brazilian Journal Veterinary Research and Animal Science, v.39, n.3, p.136-142, 2002. Available from: <https://www.scielo.br/scielo. php?pid=S1413-95962002000300005\&script $=$ sci arttext $>$. Accessed: May, 3, 2020. doi: 10.1590/S1413-95962002000300005.

MELLADO, M. et al. Factors affecting gestation length in goats and the effect of gestation period on kid survival. Journal of Agricultural Science, v.135, p.85-89, 2000. Available from: $\quad<$ https://www.cambridge.org/core/journals/journal-ofagricultural-science/article/abs/factors-affecting-gestation-lengthin-goats-and-the-effect-of-gestation-period-on-kid-survival/ AF83E5272E23FEF2A548E11345C468F0>. Accessed: Jul. 10, 2021. doi: $10.1017 /$ S0021859699007935.

MEYER, D. J. et al. Medicina De Laboratório Veterinária: interpretação e diagnóstico. São Paulo: Roca, 1995. p.308.

MILLER, D. R. et al. Metabolic maturity at birth and neonate lamb survival and growth: The effects of maternal low-dose dexamethasone treatment. Journal of Animal Science, v.87, p.3167-3178, 2009. Available from: <https://pubmed.ncbi.nlm. nih.gov/19542513/>. Accessed: Jul. 10, 2021. doi: 10.2527/ jas.2009-1825.

PADBURY, J. F. et al. Neonatal adaptation: greater sympathoadrenal response in preterm than full-term fetal sheep at birth. American Journal of Physiology-Endocrinology and Metabolism, v.248, p.E443-449, 1985. Available from: <https://pubmed.ncbi. nlm.nih.gov/3985142/>. Accessed: Jul. 10, 2021. doi: 10.1152/ ajpendo.1985.248.4.E443.

PHILIP L. B. et al. Glucocorticoid regulation of surfactant components in immature lambs. American Journal of Physiology, v.273, p.48-57, 1997. Available from: < https://journals.physiology. org/doi/full/10.1152/ajplung.1997.273.5.11048>. Accessed: Jul. 10, 2021. doi: 10.1152/ajplung.1997.273.5.L1048.

PICCIONE, G. et al. Physiological parameters in lambs during the fi rst 30 days postpartum. Small Ruminant Research, v.72, p.57-60, 2007. Available from: <https://www.sciencedirect.com/ science/article/abs/pii/S0921448806000940?via\%3Dihub>. Accessed: May, 3, 2020. doi: 10.1016/j.smallrumres.2006.04.002.

ROBERTSHAW, D. Regulação da Temperatura e o Ambiente Térmico. In: REECE, W. O. Ed. Dukes - Fisiologia dos Animais Domésticos. Rio de Janeiro: Editora Guanabara Koogan, 2006. p.897-908. 
ROONEY, S. A. Effects of cortisol administration to fetal rabbits on lung phospholipid content, composition and biosynthesis. Biochimica et Aiophysica Acta, v.450, p.121-130, 1976. Available from: <https:/www.sciencedirect.com/science/article/ abs/pii/0005276076900837>. Accessed: May, 3, 2020. doi: 10.1016/0005-2760(76)90083-7.

SCHMIDT, A. F. et al. Low-dose betamethasone-acetate for fetal lung maturation in preterm sheep. American Journal of Obstetrics and Gynecology, v.218, p.132.e1-132.e9, 2018. Available from: <https://www.sciencedirect.com/science/article/ pii/S0002937817323256>. Accessed: Jul. 10, 2021. doi: 10.1016/j. ajog.2017.11.560.

SPRENG, D. et al. Intensive care of neonates and pediatrics. Proceedings from a pre-congress symposium at the 29th world congress of the word small animal veterinary association, Rhodes, p.40-44, 2004.

THRALL, M. A. et al. Hematologia e Bioquímica Clínica Veterinária. São Paulo: Roca, 2006. p.582.
VAALA, W. E.; HOUSE, J. K. Infecção neonatal. In: SMITH, B. P. Ed. Medicina Interna de Grandes Animais. Philadelphia: Mosby Company, 2006. p.255-386.

VANNUCCHI, C. I. et al. A Clinical and hemogasometric survey of neonatal lambs. Small Ruminant Research, v.108, p.107-112, 2012. Available from: <https://www.sciencedirect.com/science/ article/pii/S0921448812002313>. Accessed: May, 3, 2020. doi: 10.1016/j.smallrumres.2012.05.013.

VARGA, J. et al. Improved Pulmonary Adaptation In Newborn Calves With Postnatal Acidosis. Veterinary Journal, v.162, p.226-232, 2001, Available from: <https:/www.sciencedirect.com/science/article/abs/pii/ S1090023301905891>. Accessed: May, 3, 2020. doi: 10.1053/tvj1.2001.0589.

ZOLLER, D. K. et al. Two treatment protocols for induction of preterm parturition in ewes - Evaluation of the effects on lung maturation and lamb survival. Small Ruminant Research, v.124, p.112-119, 2015. Available from: <https://www.sciencedirect.com/science/article/abs/ pii/S0921448815000061>. Accessed: Jul. 10, 2021. doi: 10.1016/j. smallrumres.2014.12.015. 